\title{
Slovak-Macedonian language parallels in oikonyms
}

\section{[Slovensko-macedonske jazykove paralely v ojkonymach]}

\author{
Peter Ivanic
}

\section{DOI: 10.18355/XL.2016.09.02.2-10}

Anotácia

Slovensko a Macedónsko spájajú viaceré väzby, no výskum slovensko-macedónskych vzt’ahov nemá vo vede vel'kú tradíciu. V príspevku som sa zameral na paralely v ojkonymii, pričom sledujem pomenovania obcí odvodené od slov breza, bystro, bystrý, cer, jabloň a jelša. Pri jednotlivých obciach uvádzam súčasnú podobu názvu a tiež jeho historické podoby. Následne sa zaoberám aj jeho etymológiou.

Kl'účové slová: Slovensko, Macedónsko, názvy obcí, ojkonynum, fytonynum

Vzt'ahy medzi slovenským a macedónskym jazykom možno sledovat' aj v oblasti toponymie. Významnú zložku zemepisných názvov tvoria pomenovania sídiel. Na Slovensku sa vývojom názvov obcí zaoberal predovšetkým Milan Majtán (1998). V Macedónsku v poslednom období o problematike toponomastiky vyšlo niekol'ko monografií Lubice Stankovskej (1995, 1997, 2001). Zo slovenských bádatel’ov čiastočne uvádza paralely slovenských a južnoslovanských názvov vo svojom súbornom diele Slovenský juh v stredoveku Ján Stanislav (1948). Lexikálnym vzt’ahom medzi slovenčinou a slovanskými jazykmi sa venoval Anton Habovštiak (1993). Pri analýze názvoslovia som využil aj Slovensko-macedónsky slovník (Cvetanovski- Mitrevski - Taneski, 2014).

\section{Názvy odvodené od fytonyma breza}

Slovenská obec Breznica, ktorá je v písomných prameňoch spomínaná od 15. storočia, leží v doline rieky Ondava. Písome doložená 1404 ako Wrezniche, 1408 Breza, 1430 Antiquabriza, 1454 Nagbrznicze, 1773 Nagy-Briznicze, Welka Breznicza, 1786 Nagy-Bresnize, 1808 Nagy-Breznicze, Welká Březnice, 1863 a 1888 - 1902 Nagybrezsnyice, 1873 - 1882 Nagybresnice, 1907 - 1913 Nagyberesznye, 1920 Brežnica, Velká Brežnica, 1927 Breznica (Encyclopaedia Beliana 2, 2001: 304). V dolnej časti Lednickej kotliny na severovýchodných svahoch Bielych Karpát sa nachádza Dolná Breznica. V prameňoch sa uvádza nasledovne: 1388 Breznycze, 1471 Welika Breznyacza, 1773 Alsó-Breznicz, Dolne Breznicze, 1786 AlschóBrezsnitz, 1808 Alsó-Breznicz, Dolní Březnice, 1863 - 1882, 1898 - 1902 Alsóbreznic, 1888 Alsótoposbreznic, 1892 - 1895 Alsóbrezsnic, 1907 - 1913 Alsónyiresd, 1920 Dolná Breznica (Encyclopaedia Beliana 3, 2003: 469). V jej blízkosti je Horná Breznica. Písomne doložená 1388 ako Brecznycze, 1471 Mala Breznycza, 1515 Kys Berzencze, 1773 Horné Breznicze, 1808 Hornj Březnice, 1898 - 1902 Felsöbreznic, 1907 - 1913 Felsőnyiresd, 1920 - 1979 Horná Breznica (Vlastivedny slovnik obci na Slovensku III, 1977: 430). Hronská Breznica leží na severných svahoch Štiavnických vrchov v doline Hrona. V stredoveku sa spomína v roku 1356 (Brezniche) a v roku 1424 (Brezenche) (Ivanic, 2006: 63). Od roku 1773 do roku 1927 sa uvádza ako Garam-Berzencze, Garam-Berzence, Hronská Březnice, Břežnička, Hronská Brežnica, Hronská Breznica (Majtan, 1998: 105). Na l'avom brehu Hrona sa nachádza Tekovská Breznica. V stredovekých písomných prameňoch sa uvádza ako possessio Berzenche (1276 a 1283), Berzence (1277 a 1411) a Bersenche (1312) (Ivanic, 2006: 78). V nasledovnom období sa spomína 1773 Berzencze, Bresnitz, 
Breznicze, 1786 Berzencze, Breznicze, 1808 Berzencze, Březnice, 1863 - 1902 Berzence, 1907 - 1913 Barsberzence, 1920 Tekovská Breznica (Majtan, 1998: 294). Železná Breznica leží v doline Breznického potoka v oblasti Kremnických vrchov. V stredoveku sa uvádza nasledovne: 1422 Bresnicza, 1424 Wasekethew, 1497 - 1498 Brenycza, 1517 Breznyczka (Ivanic, 2006: 86). Medzi rokmi 1773 až 1927 sa uvádza ako Vas-Bersencze, Wasch-Bersence, Vasberzence, Vaségetö, Železná Březnice, Železná Brežnica, Železná Breznica (Majtán, 1998: 394). Breznička je situovaná v Nízkych Beskydách v doline potoka Vojtovec. Prvýkrát sa uvádza v prameňoch v rokoch 1408 a 1410 pravdepodobne vd'aka kancelárskej chybe ako Nouaknizna (Ulicny, 2001: 78). V neskorších dokumentoch je zmieňovaná nasledovne: 1430 Novua Briza, 1454 Kys Brinicze, 1456 Nouabryznycza, 1506 Kys Breznycze, 1557 Breznycza Mala, 1567 Kys Breznicze, 1600 Kys Breznicze (Ulicny, 2001: 78-79). Druhá Breznička leží v severnej časti Lučenskej kotliny. V písomných prameňoch sa uvádza 1279 ako Berzenche, 1773 Berzencze, Bersentz, Breznicza, 1786 Berzencze, Breznicze, 1808 Berzencze, Březnice, Březnička, 1863 - 1902 Berzence, 1907 - 1917 Ipolyberzence, 1920 Breznička (Encyclopaedia Beliana 2, 2001: 304).

V Macedónsku sa tiež nachádza niekol'ko Brezníc. V Brodskom regióne sú záznamy o dedine Бреснuца v rokoch 1467/1468, 1481, 1545, 1569 (Stankovska, 2001: 60; Stankovska, 1997: 27). V Skopskom regióne sa uvádza v rokoch 1452/1453 Б-р-с-н-ч, 1467/1468 Бреснича а 1568/1569 Бреснича, Брезнича (Stankovska, 2001: 60-61). Ďalšia obec s názvom Бреснuца sa spomína prvýkrát vo Valovišskom regióne (dnešné Bulharsko) v roku 1465, v Melničskom regióne (dnes Bulharsko) je doložená $\mathrm{v}$ roku 1570 dedina s rovnakým názvom a aj vo Svetovračskom regióne existovala obec Бресница (Stankovska, 2001: 60-61).

$\mathrm{Na}$ Slovensku sa nachádza na hornom toku rieky Hron mesto Brezno. Prvá zmienka o ňom je z roku 1265, ked’ sa uvádza ako terra Berezun (Lacko, 2005: 30). V stredoveku sa spomína v roku 1381 ako Brizna, 1404 Bryznabanya, Bryzabanya, Brezebanya, Brezenbanya, Breznebanya, 1405 Breznebanya, 1441 Bresno, 1455 oppidum Brezno, 1503 Brys, 1516 Brazna a vnasledujúcich obdobiach ako Brezmobanya (1528, 1567, 1773, 1786), Brezno-Bánya, Brriesen (1773), Bresnobánya, Briesn (1786) (Encyclopaedia Beliana 2, 2001: 304).

Macedónska dedina Брезно v Tetovskej oblasti sa prvýkrát uvádza v roku 1841 ako Epєz̧⿻ (Stankovska, 1997: 24). V. Kičov pomenovanie píše vo forme ako Eøtзsм a D. M. Brankoff ako Brezno (Stankovska, 1997: 24).

Názvy Brezno (Брезно) a Breznica (Бресница) pochádzajú od fytonyma breza (бреза) - latinsky Betula alba < stsl. Eрtza, psl. *berza> (Stankovska, 1997: 24). Pomenovanie Breznica je odvodené zpodstatňujúcou príponou -ica z prídavného mena brezná (voda) a znamenalo „voda pretekajúca brezovinou, $t$. j. brezovým porastom “ (Lutterer - Majtan - Sramek, 1982: 66). Na Slovensku je možno doložit' súvis obecných názvov tohto typu s hydronymami. Napríklad Brezniansky potok preteká cez Brezno, Breznický potok cez Železnú Breznicu a riečka Breznica tečie cez Tekovskú Breznicu (Krsko, 2008: 28).

\section{Názvy odvodené z adjektíva bystro, bystrý}

Krajské mesto Banská Bystrica sa nachádza na strednom Slovensku v povodí Hrona. Prvýkrát sa uvádza v roku 1255 ako Nova villa Bystrice prope Lypchan. V nasledujúcich rokoch sa spomína nasledovne: 1263 Byzterchebana, 1287 Bystricia, 1303 Nousolium, 1340 Bystricia, 1400 Bystrichia, 1424 Bistriciensis civitas alias Novizolium, 1446 Nouozolium, 1773 Neozolium, Besztercz-Bánya, Neüsoll, Banska Bystryca, Banská Bystrice, 1786 Neusohl, Novisolium, Besztercze-Bánya Banská Bystrice, 1808 Neosolium, Beszterczebánya, Neusohl, Banská Bystřice, 1863 
- 1913 Besztercebánya, 1920 Baňská Bystrica, 1927 Banská Bystrica (Encyclopaedia Beliana 1, 1998: 591). Považská Bystrica leží pri vyústení riečky Domanižanky do Váhu. V stredoveku sa uvádza 1330 ako Bistrica, 1332 Bistense, Bisterse, 1368 Bestercha, 1408 Besterce, 1458 Bystricza (Vlastivedny slovnik obci na Slovensku II, 1977: 430). V neskorších obdobiach je doložená nasledovne: 1773 Vagh-Besterrcz, Bistrica, 1786 Bestercz, Besztercze, Powaska Bistrica, 1808 Vágh-Besztercze, Powážská Bystřice, 1863 - 1913 Vágbeszterce, 1920 Považská Bystrica (Majtan, 1998: 235). Súčast'ou hlavného mesta Bratislavy je Záhorská Bystrica. V prameňoch sa do konca 16. storočia uvádza nasledovne: 1314 Pistrich, 1398 Pistricz, 1408 in der Pistritzer, 1410 von Pistritz, 1433 - 1435 von Pistricz, 1548 Bystricz, 1561 Byztrycze, 1592 Beztercze (Varsik, 1984: 95). Medzi rokmi 1773 až 1971 sa vyskytujú dokumentoch názvy Besztercze, Bisternitz, Bistricze, Bisztricza, Biszternitz, Beszterce, Bystřice, Pozsonybeszterce, Bystrica, Záhorská Bystrica (Majtan, 1998: 42). V severnej časti Turčianskej kotliny je situovaná Bystrička. V písomných prameňoch sa zmieňuje nasledovne: 1258 Bistricha, 1309 Besterce, 1323 Bysterce, 1324 Biztricia, 1349 Biztrice, 1696 Byztriczka, Bstriczka, 1773 Bisztricska, Bistrička, 1786 Biztricschka, 1808 Bisztricska, Bystřička, 1863 - 1907 Bisztricska, 1913 Turócbeszterce, 1920 Bystrička (Encyclopaedia Beliana 2, 2001: 409).

V Macedónsku sa obce s pomenovaním Би́стрица nachádzajú v Tetovskom, Bitolskom a Veleskom regióne. V Tetovsku sa Би́стрица uvádza v roku 1452/1453 a 1467/1468 ako $5-c-\bar{u}-p-\imath-a$ (Stankovska, 2001: 44). V Bitolskej oblasti je Би́стрица doložená v roku 1468 a v 16. storočí ako выстрица (Stankovska, 2001: 44). Vo Veleskom regióne sa v rokoch 1258 a 1299 - 1300 spomína ako Село Бистрица а v roku 1455 ako aj v 17. - 18. storočí ako Бистрица (Stankovska, 2001: 44).

Samotné pomenovanie Bystrica vzniklo $\mathrm{z}$ adjektíva bystro (bystrý) vo význame čistý (rýchly) s pomocou prípony -ica. V prípade Banskej Bystrice názov súvisí s menom rieky a jeho pôvodný význam bol zrejme bystrá voda. Názov Bystrica vznikol z adjektíva bystrý - podl'a rýchlosti toku alebo jeho čistoty <stsl. Бъыстръ, psl. *bystrz > + sufix -ica (Krsko, 2008: 34; Stankovska, 2001: 44).

\section{Názvy odvodené od fytonyma cer}

$\mathrm{Na}$ Slovensku sa apelatívum cer vyskytuje v názvoch obcí Cerová a Cerovo. Obec Cerová leží na severovýchode Záhorskej nížiny pri úpätí Malých Karpát a patrí do okresu Senica. Obec sa spomína prvýkrát v roku 1696 ako Cerova (Vlastivedny slovnik obci na Slovensku I, 1977: 266). V neskorších obdobiach je doložená nasledovne: 1773 Czerova, Zerowa, 1786 Czerowa, 1808 Czerova, Cerowá, 1863 - 1888 Cerova (Majtan, 1998: 51). Obec Cerovo leží na Krupinskej nížine v okrese Krupina. V stredoveku sa uvádza 1273 ako Chery, 1331 Cher, 1378 Ceri, 1387 Cheer, 1388 Cheri, 1434 Chery (Bakács, 1971: 101-103). V mladšom období doložená nasledovne: 1773 Csery, Čerowo, 1786 Cscheri, 1808 Cseri, Cžerowé, 1863 - 1913 Cseri, 1920 Cerovo, Čerové, 1927 Cerovo (Majtan, 1998: 51).

V Macedónsku existujú obce Цер v Kičevskom regióne а Церово v Demirchisarsku. Dedina s názvom Цep sa prvýkrát uvádza v tureckom daňovom súpise (deftery) Bitolskej nahíje v roku 1468 ako Ч-e-p, v roku 1568 už ako Цер a v Slepčenskom kódexe sa spomína od 16. storočia vo forme Цєрz. (Stankovska, 1997: 325). Pod názvom Цеp sa zmieňuje aj v rokoch 1607, 1608, 1637 - 1638 (Stankovska, 1997: 325) V roku 1897 je známe pomenovanie vo forme Tcher a v roku 1907 Tzer (Stankovska, 1997: 325). Церово sa prvýkrát uvádza ako súčast' Skopského ejáletu v rokoch 1467 - 1468 vo forme Черново, ale v tureckých defteroch Bitolskej nahíje z rokov 1468 až 1568 sa už vyskytuje pod názvom Церово a v Slepčenskom kódexe sa spomína od 16. storočia vo forme Цєрово (Stankovska, 1997: 327). V neskorších 
obdobiach je doložená nasledovne: 1623 - 1797 Церово, 1897 Tserovo a 1905 Tzerovo (Stankovska, 1997: 327).

Pomenovania Cerová, Cerovo, Цер, Церово sú nepochybne odvodené od fytonyma cer (uep) - latinsky Quercus cerris (Stankovska, 1997: 325).

\section{Názvy odvodené $\mathrm{z}$ apelatíva jabloň}

$\mathrm{Na}$ Slovensku sú z apelatíva jabloň odvodené názvy obcí Jabloň, Jablonec, Jablonica, Jablonka, Jablonov, Jablonov nad Turňou, Jabloňovce, Nižná Jablonka, Vyšná Jablonka, Jablonové v okrese Bytča a Jablonové v okrese Malacky. Slovenská obec Jabloň je situovaná v doline potoka Výrava v Laboreckej vrchovine. Písomne doložená 1379 Jablanka, 1405, 1436, 1521 Jablonka, 1543, 1548, 1560 Jablonya, 1610, 1635 Thoth Jablonia, 1567 Jeblonia, 1582 Toto Jablona, 1635 Thot Jablonia, 1623 Tot Jablonya, 1773 Toth-Jablonya, Jablona, 1786 Jablanya, Tóth-Jablanya, 1808 Tót-Jablonya, Slowenská Jabloň, Slowenská Jablonica, 1863, 1888 - 1902 Tótjablonya, 1873 - 1882 Tótjablanya, 1907 - 1913 Tótalmád, 1920 Jablon̆ (Encyclopaedia Beliana 7, 2013: 284). Ned'aleko Pezinka na Trnavskej pahorkatine sa nachádza Jablonec. Písomne doložený 1342, 1405 Zamol, 1416 Zwmoly/Zamol, 1418 Zamol, 1543 Helmisch oder Niclasshouen, 1773 Helmes, Helmesch, Halmess, 1786 Helmesch, Halmesch, 1808 Helmes, Halmeš, 1863 Helmes, 1873 - 1882 Halmes, 1888 - 1913 Halmos, 1920 Halmeš, 1927 - 1948 Jablonec, Halmeš, 1948 Jablonec (Encyclopaedia Beliana 7, 2013: 284-285). Jablonica leží na okraji Záhorskej nížiny. Prvýkrát sa spomína v roku 1262 Jobluncha (Vlastivedny slovnik obci na Slovensku I, 1977: 500). Od 18. storočia sa uvádza nasledovne: 1773 Jabloncza, Jablonitz, Jablonicza, 1786 Jabloncza, Jablonicz, 1808 Jabloncza, Jablonitz, Jablonica, 1863 - 1873 Jablonca, 1877 - 1907 Jablonic, 1913 Jablánc, 1920 Jablonica (Majtán, 1998: 115). Jablonka sa vyčlenila v roku 1955 z mesta Myjava (Encyclopaedia Beliana 7, 2013: 286). Na úpätí Levočských vrchov je situovaný Jablonov. Písomne doložený 1235 ecclesie Scepusiensis sanctus Martini, 1249, 1311, 1313 Almas, 1318 Almas, Halmas, 1321 Jabulanc, 1346 Sraibersdorph, 1561 Almas, 1773 Almás, Jablonow, 1786 Almásch, Jablonow, 1808 Almás, Apfelsdorf, Jabloňow, 1863 - 1902 Almás, 1907 - 1913 Szepesalmás, 1920 Jablonov (Encyclopaedia Beliana 7, 2013: 286). Jablonov nad Turňou sa rozkladá v Turnianskej kotline. V písomných prameňoch sa uvádza nasledovne: 1332 - 1335 Almas, Alma, 1430 1561, 1578, 1598 Almas, 1773, 1808, 1863, 1888 - 1902 Almás, 1786 Almásch, 1873 - 1882 Tornaalmás, 1907 - 1913, 1945 - 1948 Szádalmás, 1920 Jablonov, 1927 - 1938, 1945 - 1948 Jablonov nad Turnou, Szádalmás, 1948 - 1973 Jablonov nad Turnou, 1973 Jablonov nad Turňou (Encyclopaedia Beliana 7, 2013: 287). Jabloňovce vznikli v roku 1944 zlúčením obcí Dolný Almáš a Horný Almáš. Dolný Almáš je písomne doložený 1245, 1313, 1333 Almas, 1388 Almaas, Almas, 1499 Alsoalmas, 1500 Almas, 1522, 1554 Almas, 1663/1664 Tót Almás, 1773 AlsóAlmas, Unter-Almasch, Dolny Almass, 1786 Alschó-Almásch, 1808 Alsó-Almás, 1863 - 1913 Alsóalmás, 1920 Dolný Almáśs, Dolná Ves, 1927 - 1944 Dolný Almáš. Horný Almáš sa spomína v prameňoch nasledovne: 1245, 1313, 1333 Almas, 1491 Felsewalmas, 1500 Almas, 1517 Felsewalmas, 1522 Almas, 1663/1664 Felsö Almás, 1773 Felsö-Almas, Ober-Almasch, Horny Almass, 1786 Felschö-Almásch, 1808 Felsö-Almás, 1863 - 1913 Felsöalmás, 1920 Horný Almáš, Horná Ves, 1927 - 1944 Horný Almáš (Encyclopaedia Beliana 7, 2013: 286). Jablonové v okres Bytča leží v doline Hradnianskeho potoka. Písomne doložené 1268 Jabluna, 1400 Jablonowa, 1405 Jablonowe, 1458, 1469, 1498, 1526 Jablonowe, 1560 Jablonow, 1584, 1586 Jablonowe, 1712 Jablonove, 1773 Jablonove, Jablonowe, 1786 Jablonowe, 1808 Jablonova, Jabloňowé, 1863 Jablonové, 1873 - 1877 Jablonove, 1882 - 1888 Jablonfalva, 1892 - 1902 Jablonófalu, 1907 - 1913 Almásfalu, 1920 Jablonové 
(Encyclopaedia Beliana 7, 2013: 286). Jablonové v okrese Malacky je situované na rozhraní Záhorskej nížiny a Malých Karpát. Písomne doložené 1206, 1208, 1216 Jablan, 1231 Yablan, 1773 Almás, Apfels-Pach, Jablonowe, 1786 Almásch, Apfelbach, Jablonow, 1808 Almás, Apfelsbach, Jabloňov, 1863 - 1907 Almás, 1913 Pozsonyalmás, 1920 Jablonové (Encyclopaedia Beliana 7, 2013: 286). Nižná Jablonka sa nachádza $\mathrm{v}$ doline rieky Udavy. V písomných prameňoch sa uvádza nasledovne: 1543, 1548, 1601 Also Jablonka, 1773 Alsó-Jablanka, Nisna Jablonka, 1786 Alschó-Jablonka, 1808 Alsó-Jablónka, Dolní Jabloňka, Nižssí Jabloňka, 1863 1902 Alsójablonka, 1907 - 1913 Alsóalmád, 1920 - Nižná Jablonka (Majtan, 1998: 203; Ulicny 2001: 351). Vyšná Jablonka leží tiež v doline rieky Udavy. Písomne doložená 1543 ako Felswe Jablonka, 1623 Felseo Jablonka, 1773 Felsö-Jablanka, Wisna Jablanka, 1786 Felschö-Jablonka, 1808 Felsö-Jablónka, Horni Jabloňka, Wyšssí Jabloňka, 1863 - 1902 Felsöjablonka, 1907 - 1913 Felsöalmád, 1920 - Vyšná Jablonka (Majtan, 1998: 336; Ulicny 2001: 612-613).

V stružskom regióne sa nachádza Јабла́ница. V rokoch 1342 - 1345, 1467, 1582 a 1857 sa spomína ako Genо навманнса (Stankovska, 2001: 171). V 19. storočí je písomne doložená ako Gens Aвмaннсa (Stankovska, 2001: 171).

Názvy obcí Jabloň, Jablonec, Jablonica (Јабла́ница), Jablonka, Jablonov, Jablonov nad Turňou, Jabloňovce, Nižná Jablonka, Vyšná Jablonka a Jablonové pochádzajú z apelatíva jablon̆ (јаблан) <stsl. навлань, psl. *jabolnъ>. Názov Jablonica (Јабла́ница) bol vytvorení s príponou miesta -ica (Stankovska, 2001: 171). V starších názvoch niektorých slovenských obcí sa uplatnilo mad'arské pomenovanie pre jablko - almáš. Rudolf Krajčovič predpokladá, že názov bol motivovaný výskytom divo rastúcich jabloní, ktoré sa v stredoveku využívali v strategických bodoch ako prirodzená zátarasa (Krajcovic, 2005: 75, 154; Ivanic, 2011: 161).

\section{Názvy odvodené od fytonyma jelša}

Názvy slovenských obcí Jalšové, Jalšovík, Jelšava, Jelšovce, Jelšovec, Nižná Olšava, Olešná, Olšovany, Olšavica, Ol’šavce, Ol’šavka, Ol’šinkov, Ol’šov, Vyšná Olšava súvisia s apelatívom jelša/ol’ša. Jalšové sa nachádza na južnom výbežku Považského Inovca v okrese Hlohovec. Písomne doložené 1352 ako Wlseu, 1356 Jelsew, 1453 Jalswa, 1773 Jalso, Jalschowe, 1786 Jalschócz, 1808 Jalsócz, Jalssowce, 1863 - 1913 Jalsó, 1920 Jalšové, Jalšov, 1927 Jalšové (Majtan, 1998: 118; Vlastivedny slovnik obci na Slovensku I, 1977: 507). Jalšovík leží na Krupinskej výšine $\mathrm{v}$ doline potoka Jalšovík v okrese Krupina. Písomne je v stredoveku spomínaný 1418 ako Jelsouk, Jelsoukh, 1446 Utraque Elsko, 1470 Elsok, Felsewelsok, 1488 Jelsok, 1526 Elsok utraque (Bakacs, 1971: 84). V dokumentoch z neskoršieho obdobia je zmieňovaný nasledovne: 1542 Also Alsok, Felsew Alsok, 1578 Also Jalsok, Felseo Jalsok, 1773 Alsok, Jalssowik, 1786 Alschok, Jalssowec, Jalssowik, 1808 AlsóAlsók és Felsö-Alsók, Jalssowík, 1863 - 1900 Alsóalsók, Felsöalsók, 1902 - 1913 Bozókalsók, 1920 Jalšovík (Majtan, 1998: 118; Vlastivedny slovnik obci na Slovensku I, 1977: 507). Mesto Jelšava vokrese Revúca leží na rozhraní Slovenského Rudohoria a Slovenského Krasu v doline Muráňa. Písomne je doložené 1243 ako Ilswa, 1271 Elsua, 1287 Ilsua, 1299 Ilsva, 1327 Ylsua, 1344 Elswa, 1406 Elsva, 1427 Ilswa, 1435 Ilswa, 1438, 1453 1466, 1469 Ilswa, 1516 Iolswa, 1564 Jelssawa, 1573 Jolssova, 1582 Ölch alias Ilschwa, 1594 Oltcz, 1598 Jelsowa, Josuach, 1773 Alnovia, Jolsva, Elesch, Jalssowa, 1786 Alnovia, Eltsch, Jelschau, 1808 Jolsva, Eltsch, Jelssawa, 1863, 1888, 1898 - 1900 Jólsva, 1873 - 1882, 1892 1895, 1902 - 1913, 1938 - 1945 Jolsva, 1920 - 1938, 1945 Jelšava (Majtan, 1998: 122; Skalska, 2009; Vlastivedny slovnik obci na Slovensku I, 1977: 519). Jelšovce sa nachádzajú v juhovýchodnej časti Nitrianskej sprašovej pahorkatiny na terase rieky 
Nitra. Písomne uvádzané v stredoveku 1326 ako Egurzegh, 1327 Egurzegh, 1329 Egerseg, 1332 Eguesseg (Gyorffy, 1998: 378). V neskorších obdobiach je obec doložená nasledovne: 1773 Egerszegh, 1786, 1808, 1863 - 1877, 1888 Egerszeg, 1882, 1892 - 1913 Nyitraegerszeg, 1920 Jagerseg, Egerseg, 1927 - 1948 Jagersek, Egerszek, 1948 Jelšovce (Majtan, 1998: 122). Jelšovec situovaný blízko Lučenca na pravom brehu rieky Ipel' je prvýkrát písomne doložený v 1573 ako Jelsewcz, Jelsoch (Vlastivedny slovnik obci na Slovensku I, 1977: 521). Medzi rokmi 1773 až 1948 sa vyskytujú v dokumentoch názvy Jelsöcz, Jelschócz, Jelsöcz, Jelssowec, Jelsöc, Jelšovec, Jelšovec, Jelsöc, Jelšovec (Majtan, 1998:122). Nižná Olšava leží v dolnej časti údolia Ol’šavy v okrese Stropkov. Riečka Ol’šava sa uvádza v roku 1356 ako rivulus Ilsuapotoka. Obec je písomne doložená 1410 ako Alsoilswa, 1493 Alsoolchva, 1519 Also Olsva, 1585 Also Olswa, 1808 Alsó-Ósva, Alsó-Olsva, Nižni Olssawy, 1863 Alsóolysava, 1873 - 1882 Alsóolcsva, 1888 - 1913 Alsóolsva, 1920 - 1948 Nižná Ol’šava, 1948 Nižná Olšava (Majtan, 1998: 203; Ulicny, 2001: 352-353). Olešná sa rozprestiera v Turzovskej vrchovine v doline Olešany. Písomne doložená 1619 ako Olessna, 1773 Olesna, Olessna, 1786 Ollezna, 1808 Olesna, Olessná, 1863 Oleszna, 1873 - 1882 Óleszna, 1888 - 1902 Olesna, 1907 - 1913 Berekfalu, 1920 Olešná (Majtan, 1998: 212; Vlastivedny slovnik obci na Slovensku I, 1977: 507). Olšovany sa nachádzajú v juhovýchodnej časti Košickej kotliny na pravom brehu rieky Olšava. V stredoveku sú doložené 1272 - 1290 ako Ilswa, 1290 Elswa, 1332 - 1335 Oslua, Elswa, Ilsua, 1350 Olswa, 1427 Ozwa, 1553 Oswa (Varsik, 1977: 99). Medzi rokmi 1773 až 1948 sa v dokumentoch zmieňujú názvy Osva, Olssowjany, Oschwa, Olschawjani, Ósva, Olsva, Olssowany, Olssawjany, Ósva, Osva, Olšovjany, Ol’šoviany a Olšovany (Majtan, 1998: 213). Olšavica leží vo východnej časti Levočských vrchov. Písomne doložená 1308 ako Elsawycha, 1773 Olysavka, Olschawka, Olsawka, 1786 Olyschawka, 1808 Olsavka, Olysavka, Olssawka, 1863 Olsafka, Olysavka, 1873 Olsavka, 1877 - 1902 Olysavka, 1907 - 1913 Kisolsva, 1920 Olšavka, 1927 Ol’šavka (Majtan, 1998: 212; Stevik, 2005: 30). Ol’šavce sú situované v juhozápadnej časti Ondavskej vrchoviny vokrese Bardejov. V stredoveku sa uvádzajú: 1383 Alsouch, 1384 Olsoch, 1427 Orsolch, 1447 Olsocz, 1493 Orsolcz, 1543 Orsocz (Ulicny, 1990: 221-222). V neskorších obdobiach sú doložené nasledovne: 1773 Orsocz, Orssawcze, 1786 Orschocz, Orssawce, 1808 Orsócz, Orssowce, 1863 - 1902 Orsóc, 1907 - 1913 Orsós, 1920 - 1965 Ol’śavce, 1965 1973 Olšavce, 1973 Ol’šavce (Majtan, 1998: 212). Katastrom spišskej obce Ol`šavka v okrese Spišská Nová Ves preteká zo severu smerom na juh potok Ol’šavec, ktorý sa vlieva do Hornádu. Obec je písomne doložená 1301 ako Olsaua, 1378 Olsova, 1583 Olssawka, 1773 Olysavka, Olschawka, Olsawka, 1786 Olyschawka, 1808 Olsavka, Olysavka, Olssawka, 1863 Olsafka, Olysavka, 1873 Olsavka, 1877 - 1902 Olysavka, 1907 - 1913 Kisolsva, 1920 Olšavka, 1927 Olšsavka (Majtan, 1998: 212; http://www.olsavka.sk). Iná Ol’šavka leží v Nízkych Beskydách a patrí do okresu Stropkov. Písomne doložená 1470 ako Olsaffka, 1497 Osawka, 1548 Olsawycha, 1618 Olsawka, 1773 Olysavka, Olssawka, 1786 Olyschawka, 1808 Olsavka, Olysavka, Olssawka, 1863 Olsawka, 1873 - 1882, 1892 - 1902 Olysavka, 1888 Olysafka, 1907 - 1913 Kisolysó, 1920 Olšavka, Šarišská Olšavka, 1927 - 1948 Olšavka, 1948 - 1973 Olšavka, 1973 Ol’šavka (Majtan, 1998: 213; Ulicny, 1990: 222-223). Ol’šinkov v okrese Medzilaborce sa nachádza na severnom okraji Laboreckej vrchoviny. Založený bol na valašskom práve. Písomne sa spomína 1543 ako Olsynkov, 1582 Olsinka, 1623 Olsinko, 1773 Olsinko, Olssinko, 1786 Olyschinka, 1808 Olsinkó, Olysinka, Olssinkow, 1863 Olysinkó, 1873 - 1902 Olsinkó, 1873 - 1902 Olsinkó, 1907 - 1913 Meggyfalu, 1920 Olšinkov (Majtan, 1998: 213; Ulicny, 2001: 371-372). Ol’šov v okrese Sabinov leží na styku Levočských vrchov so Šarišskou vrchovinou. Písomne doložený 1309 ako Olsowa, 1330 Elza, Elsua, 1336 Olschwicha, 1337 Olsva, 
1375 Olsauicha, 1437 Olsouicha, 1543 Orsowycza, Olsouicza, 1773 Ollyso, Olyso, Olsso, 1786 Olyscho, 1808 Olsó, Olysó, Olssawa, Olssowce, 1863 - 1913 Olysó, 1920 Ol'šov, Ol'šovce, 1927 Ol'šov (Majtan, 1998: 213; Ulicny, 1990: 223-224). V doline riečky Ol'šavy v Ondavskej vrchovine sa rozprestiera Vyšná Olšava. Písomne doložená 1382 ako Elsewa, 1390 Elsua, 1410 Ilswa, 1471 Felsewolswa, 1493 Feslewokhwa, 1550 Felso Olsua, 1582 Felseoochua, 1623 Felso Olsava, 1808 FelsöÓsva, Felsö-Olsva, Wissni Olssawy, 1863 Felsöolysova, 1873 - 1882 Felsöolcsva, 1888 - 1913 Felsöolsva, 1920 - 1948, 1973 - 1980 Vyšná Ol'šava, 1948 - 1973, 1981 Vyšná Olšava (Majtan, 1998: 336; Ulicny, 2001: 613-614).

V Macedónsku v Tetovskej oblasti na planine Šar sa nachádza obec s názvom Јелошник. V tureckých defteroch Tetovského ejáletu z rokov 1452 1453, 1467 - 1468 a 1568 - 1569 sa uvádza názov Јелашник a v písomných prameňoch Kláštora sv. Atanazija v Lešku sa vyskytuje vo forme Eп॰шмнкъ alebo Епошмик. Z roku 1905 je známe aj pomenovanie Elochnik (Stankovska, 1997: 120121).

Slovenské mesto Jelšava má pomenovanie odvodené od rovnomennej rieky, ktorá sa však v súčasnosti nazýva Muráň. Táto sa priamo spomína v roku 1243 ako Ilsua. Názov pochádza od slovenského slova jelša a vytvorený bol príponou -ava. Mad'ari ho prevzali vo forme Jolsva a Nemci Eltsch (Öltsch) (Varsik, 1990: 93-94). Nižná Olšava a Vyšná Olšava ležia na riečke Olšava, ktorá sa vlieva do Ondavy (Varsik, 1990: 146). Na Slovensku je od apelatíva jelša odvodené pomenovanie aj d'alších vodných tokov (Krsko, 2008: 97-98). Celkove možno predpokladat', že názvy obcí Jalšové, Jalšovík, Jelšava, Jelšovce, Jelšovec, Nižná Olšava, Olešná, Olšovany, Olšavica, Ol’šavce, Ol’šavka, Ol’šinkov, Ol’šov, Vyšná Olšava а Јелошник boli odvodené od fytonyma jelša (елха) - latinsky Alnus <stsl. єльха/ єАъха> (Stankovska, 1997: 122-123).

Hlavnú čast' príspevku tvoria záznamy súčasných názvov obcí a ich jednotlivé historické podoby. V niektorých prípadoch ide o pomenovanie, ktoré sa už dnes nepoužíva. V prípade obcí na Slovensku sa v minulosti uplatnilo často aj mad’arské a nemecké pomenovanie. Tento fakt súvisí priamo s historickým vývojom. Na území historického Macedónska sa aj v tureckých daňových súpisoch z 15. a 16. storočia vyskytujú len slovanské názvy. Na záver možno konštatovat', že sledované ojkonymá sú zastúpené na Slovensku ako aj v Macedónsku vo väčšom počte. Väčšinou majú rovnaký slovotvorný základ. Sledovanie a porovnávanie kultúrnych a jazykových segmentov má význam pre poznávanie jedinečnosti historického vývoja jednotlivých regiónov i pre komplexné poznanie dejín štátov (Hetenyi, 2015: 78).

\section{Bibliograpic references}

BAKACS, I. 1971. Hont varmegye Mohacs elott. Budapest: Akademiai Kiado. CVETANOVSKI G. - MITREVSKI L. - TANESKI Z. 2014. Slovacko-makedonski recnik = Slovensko-macedonsky slovnik. Skopje: Vinsent grafika. ISBN 9786084571261

ENCYCLOPAEDIA Beliana 1. 1998. Bratislava: Encyklopedicky ustav SAV a Veda. ENCYCLOPAEDIA Beliana 2. 2001. Bratislava: Encyklopedicky ustav SAV a Veda. ENCYCLOPAEDIA Beliana 3. 2003. Bratislava: Encyklopedicky ustav SAV a Veda. ENCYCLOPAEDIA Beliana 7. 2013. Bratislava: Encyklopedicky ustav SAV a Veda. GYÖRFFY, G. 1998. Az Arpad-kori Magyarorszag torteneti foldrajza IV. Budapest: Akademiai Kiado. ISBN 9630575043

HABOVSTIAK, A. 1993. Zo slovensko-slovanskych lexikalnych vztahov (so zretelom na lingvisticku geografiu). Bratislava: Veda. ISBN 8022403660 
HETENYI, M. 2015. Niektore aspekty kulturnej, umeleckej a osvetovej cinnosti mesta Nitra v rokoch 1939 - 1945. In Konstantinove listy, vol. 8, p. 78-88. ISSN 13378740.

IVANIC, P. 2006. Vyvoj struktury osidlenia horneho a stredneho Pohronia v stredoveku. Nitra (nepublikovana dizertacna praca).

IVANIC, P. 2011. Toponyma a stredoveka cestna siet na Pohroni a Poipli. In Konstantinove listy, vol. 4, p. 159-169. ISSN 13378740.

KRAJCOVIC, R. 2005. Zive kroniky slovenskych dejin skryte $v$ nazvoch obci a miest. Bratislava: Literarne informacne centrum. ISBN 8088878993

KRSKO, J. 2008. Hydronymia povodia Hrona. Banska Bystrica: Univerzita Mateja Bela. ISBN 9788080836115

LACKO, R. 2005. Kapitoly zo starsich dejin mesta. In Brezno v premenach casu. Brezno: Mesto Brezno. ISBN 8089151078

LUTTERER, I. - MAJTAN, M. - SRAMEK, R. 1982. Zemepisna jmena Ceskoslovenska. Praha: Mlada fronta.

MAJTAN, M. 1998. Nazvy obci Slovenskej republiky (Vyvin v rokoch 1773 - 1997). Bratislava: Veda. ISBN 8022405302

MATAIA, I. 2011. Promjene imena naselja na hrvatskome podrucju u Svjetlu administrativnih odredenja od 1860. do 1960. godine (Changes of the settlements' names in the Croatian lands in light of the administrative determinations in the period from 1860 to 1960). In Folia Onomastica Croatica, vol. 20, p. 121-149.

SKALSKA, M. 2009. Jelsava a Jelsavske panstvo v stredoveku. K osidleniu severneho Gemera. MartIn Matica slovenska. ISBN 9788070909478

STANISLAV, J. 1948. Slovensky juh v stredoveku I. - II. MartIn Matica slovenska.

STANKOVSKA, L. 1997. Makedonska ojkonimija, kniga vtora. Skopje: Metamorfoza. ISBN 9989726035

STANKOVSKA, L. 2001. Toponimite so sufiksot -ica vo Makedonija. Prilep Skopje: Institut za staroslovenska kultura - Matica Makedonska. ISBN 9989483590 , 9989987041

STEVIK, M. 2005. Z dejin osidlenia a verejnej spravy stredovekeho Spisa (stredoveky Spis). Stara Lubovna: Lubovnianske muzeum v Starej Lubovni. ISBN 8096923404

TANESKI, Z. 2015. Šturova kodifikacia slovenciny a macedonska jazykova otazka. In Philologica LXVII - Universitas Comeniana (Zborník Filozofickej fakulty Univerzity Komenského). Bratislava: Univerzita Komenskeho, 2011, pp. 55-64. ISBN 978-80-223-2967-5

TANESKI, Z. 2015. Vzajomne hladanie identity: slovensko-macedonske literarne, kulturne a jazykove kontakty v 20. storoci a v sucasnosti, 2014. In. Konstantinove listy. ISSN 1337-8740, Vol. 7, n. 2 (2014), pp. 61-67. TANESKI, Z. 2015. Prostorite na tekstot. Skopje: Makedonika litera.

ULICNY, F. 1990. Dejiny osidlenia Sarisa. Kosice: Vychodoslovenske vydavatelstvo. ISBN 8085174030

ULICNY, F. 2001. Dejiny osidlenia Zemplinskej zupy. Michalovce: Zemplinska spolocnost'. ISBN 8096857916

VARSIK, B. 1977. Osidlenia Kosickej kotliny III. Bratislava: Veda.

VARSIK, B. 1990. Slovanske (slovenske) nazvy riek na Slovensku a ich prevzatie Madarmi v 10. - 12. storoci. Bratislava: Veda. ISBN 8022401633

VIDOVIC, D. 2012. Pogled u toponimiju Makarskoga primorja (An overview of the toponymy of the Makarska Region). In Folia Onomastica Croatica, vol. 21, p. 207232. ISSN 13300695

VLASTIVEDNY slovnik obci na Slovensku I. 1977. Bratislava: Veda. 
VLASTIVEDNY slovnik obci na Slovensku II. 1977. Bratislava: Veda. VLASTIVEDNY slovnik obci na Slovensku III. 1978. Bratislava: Veda.

Words: 3928

Characters: 28122 (15, 62 standard pages)

Assoc. prof. Peter Ivanič, PhD.

Institute for Research of Constantine and Methodius' Cultural Heritage

Constantine the Philosopher University in Nitra

Štefánikova 67, 94974 Nitra

Slovakia

pivanic@ukf.sk 